\title{
Publisher Correction: A CRISPR-Cas9-based reporter system for single-cell detection of extracellular vesicle-mediated functional transfer of RNA
}

Olivier G. de Jong (1D, Daniel E. Murphy, Imre Mäger (1), Eduard Willms, Antonio Garcia-Guerra, Jerney J. Gitz-Francois, Juliet Lefferts (1D), Dhanu Gupta(D), Sander C. Steenbeek, Jacco van Rheenen, Samir El Andaloussi, Raymond M. Schiffelers, Matthew J.A. Wood \& Pieter Vader (B)

Correction to: Nature Communications https://doi.org/10.1038/s41467-020-14977-8, published online 28 February 2020.

The original version of this Article contained errors in Fig. 4; in panel $b$ the Rab27A column was incorrectly labelled as Rab24A, and in panel $f$ the VAV2 column was incorrectly labelled as VAn2. These have been corrected in both the PDF and HTML versions of the Article.

Published online: 31 March 2020

(c) (i) Open Access This article is licensed under a Creative Commons Attribution 4.0 International License, which permits use, sharing, adaptation, distribution and reproduction in any medium or format, as long as you give appropriate credit to the original author(s) and the source, provide a link to the Creative Commons license, and indicate if changes were made. The images or other third party material in this article are included in the article's Creative Commons license, unless indicated otherwise in a credit line to the material. If material is not included in the article's Creative Commons license and your intended use is not permitted by statutory regulation or exceeds the permitted use, you will need to obtain permission directly from the copyright holder. To view a copy of this license, visit http://creativecommons.org/licenses/by/4.0/.

(c) The Author(s) 2020 